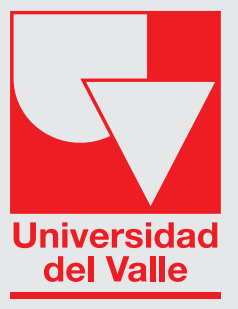

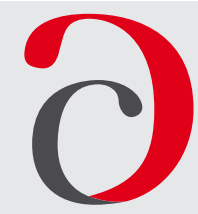

Cuadernos de Administración
Journal of Management

Print ISSN: 0120-4645 / E-ISSN: 2256-5078 / Short name: cuad.adm.

Pages: 92-104 / Vol: 36 / Issue: 66 / Jan. - Apr. 2020

Faculty of Administration Sciences / Universidad del Valle /

Cali - Colombia

\title{
Financing Decisions for Creative and Cultural SMEs in Bogotá, Colombia
}

\author{
Decisiones de financiación en las Pymes creativas y culturales de Bogotá, Colombia
}

\section{* Paula Andrea Navarro PéreziD}

Assistant Professor, Department of Accounting, Faculty of Economic, Business, and Accounting Sciences, Fundacion Universitaria Los Libertadores, Bogotá, Colombia. e-mail: panavarrop@libertadores.edu.co

\author{
Article of Scientific and Technological Research \\ Submitted: 20/08/2019 \\ Reviewed: 03/12/2019 \\ Accepted: 14/02/2020 \\ Thematic lines: Administration and Organizations \\ JEL classification: G30, G32, G41 \\ DOI: https://doi.org/10.25100/cdea.v36i66.8426
}

\section{Abstract}

This article aims to characterize financing decision-making processes in SMEs belonging to the cultural and creative sector of the city of Bogota (Colombia), analyzing these processes in the light of the main theories of capital structure documented in the financial literature since the 1950s. To this effect, an empirical analysis methodology focused on behavioral factors is carried out through the application of surveys and interviews to the target population. Then, results are compared with the assumptions of the financial theories. As a result, it was found that, in the case of the cultural and creative SMEs in Bogotá, financing decision-making process is somewhat similar to that stated by the theories of pecking order, business strategy, free cash flow, and behavioral finance; nevertheless, there are differences associated with contextual factors such as needs, preferences, competitiveness, and availability of funding sources. On the other hand, the theories of trade-off, signaling, and static equilibrium differ largely from the results found in this study.

Keywords: Capital structure, Financing decisions, Cultural and creative SMEs, Financing for SMEs.

\section{Resumen}

El presente artículo pretende realizar una caracterización de los procesos de toma de decisiones de financiación en las pequeñas y medianas empresas (Pymes de ahora en adelante) pertenecientes al sector cultural y creativo de la ciudad de Bogotá D.C., analizando dichos procesos a la luz de lo propuesto por las principales teorías de estructura de capital documentadas en la literatura financiera desde la década de los cincuenta. Para ello, se lleva a cabo una metodología de análisis empírico enfocada en factores comportamentales, mediante la aplicación de encuestas y entrevistas a la población objetivo y se comparan los resultados obtenidos con los supuestos de las teorías financieras. Como resultado, se obtuvo que, por lo menos para el caso de las Pymes culturales y creativas de Bogotá, la toma de decisiones de financiación se asemeja en cierto grado a lo planteado por las teorías de pecking order, estrategia empresarial, free cash flow y finanzas conductuales; sin embargo, existen diferencias asociadas a factores contextuales como la necesidad, las preferencias, la competitividad y la disponibilidad de fuentes de financiación. Por su parte, las teorías 
de trade-off, signaling y equilibrio estático, difieren en mayor medida de los resultados encontrados en el estudio.

Palabras clave: Estructura de capital, Decisiones de financiación, Pymes culturales y creativas, Financiación para Pymes.

\section{Introduction}

Three fundamental decisions that companies must make have always been at the forefront of corporate finance research: financing, investment, and dividends policy. Regarding the first decisions, through the years, academic and corporate literature has documented information related to the capital structure of companies, which Jiménez and Palacin (2007, p. 9) define as "the combination of internal and external resources used by companies to finance their investments." Research has mainly focused on the effects of this structure on the performance and profitability of companies, and the existence of possible optimal capital structures for the corporate world. Despite the progress in the academic and research areas, there is currently no universal theory on capital structure, nor reasons to expect one in the near future (Myers, 2001).

Traditionally, most of the research in this field has focused on large listed companies with access to various sources of capital. These companies are mostly interested in knowing the prevailing criteria when making financing decisions and on the effects of these decisions on financial indicators such as, inter alia, performance, productivity, and company value. However, the literature documenting research results on the capital structure of SMEs is far more recent and has not experienced such a widespread development.

Nowadays, insufficient access to financing and poor financial decision-making are considered as some of the leading causes of corporate failure for smaller enterprises (Vera-Colina, Melgarejo-Molina, and MoraRiapira, 2014). Therefore, further studies must be conducted to help characterize and determine the financial decision-making processes for enterprises that do not have various capital sources at their disposal, first, to compare the current theories or propose new theories, and, second, to create enhancement and growth strategies for these entities.

The primary purpose of this paper is to characterize the financing decision-making process for SMEs in the creative and content industry in the city of Bogotá, D.C., comparing whether or not any of the current theories that analyze capital structures might explain said financing decisions. To achieve this, we used an empirical analysis methodology based on surveys and interviews with a sample selected through simple random sampling, analyzing the results under said theories.

This paper starts with a literature review of the traditional and alternative theories proposed to explain the capital structure and corporate financing decision-making. At the end of this review, we specifically analyze the theories studied in the field of SMEs, comparing their main assumptions with the particular context of these enterprises. Then, we present the methodology used for this study, describing its design and the application of the surveys and interviews. Later, we present the results obtained from the data collection and analysis, comparing them to the various theories, emphasizing on the disparities and turning points observed. Finally, we discuss the findings and present a series of conclusions.

\section{Literature Review}

The capital structure of companies has been extensively discussed by the academic literature, as it has significant effects on the capital cost and the value of the company. In financial terms, the capital cost defines the performance required from the individuals who have contributed resources to the company, whether as debt or equity. It consequently determines the criteria to make investment, financing, capitalization, and future cash flows deductions decisions (Vargas, 2012).

Below we present a summary of the main theories propose by the academia on capital structures, their assumptions, and limitations. 


\subsection{Traditional theories on companies' capital structure}

2.1.1.Efficient-market hypothesis. Ingeneral financial terms "a market in which the prices 'entire reflect' the available information is an efficient market" (Fama, 1970 p. 383); therefore, we could expect that, under this market, all the information is available to all of the participants. Under this hypothesis, and regarding the firms' capital structure, Modigliani and Miller (1958) suggested that any decision made between financing with debt and financing with equity capital has no significant effects on the firm's value. According to this proposal, the capital cost is insignificant compared to a company's market value; therefore, any variation therein has no significant effects, thus being irrelevant to the capital structure (Myers, 2001).

Although some authors consider Modigliani \& Miller's proposals as the "genesis" of capital structure theories (Bradley, Jarrell, and Kim, 1984), the applicability of this theory has been disputed, leading to several new theories to cover its gaps. At first, Modigliani $\&$ Miller's proposals are only valid under a perfect market, i.e., a market with no taxes, asymmetrical information, or agency costs (Myers, 2001), which is not the case of most global markets.

Subsequently, Modigliani \& Miller adjusted their model by introducing the effect of tax rates to be covered by enterprises over their profits in the effect theory (Modigliani and Miller, 1963), recognizing that there is a tax advantage to being in debt, as interests are tax-deductible in most countries. Therefore, there is a motivation for the capital structure to be composed mainly of debt; however, other studies mentioned several limitations to these benefits (Rivera, 2002).

Additional theories on capital structure have emerged in the framework of imperfect markets. They have focused on trying to answer how such decisions are made in markets affected by tax rates, asymmetric information, and agency costs.

2.1.2. Trade-off theory. This theory focuses mainly on the existence of the taxes the companies must pay. One of the main flaws in Modigliani \& Miller's proposal that theorists have observed since the 60s is that most governments tax the profits of firms and, additionally, the interests payable on debts are deductible of said income tax. Therefore, in theory, firms are motivated to increase their debt ratio provided the interests they pay cause fewer taxes, eventually increasing the firm's value.

Under this perspective, reasonably high debt ratios are justified within the firms. However, the theory also proposes that increasing the debt is only reasonable to the point that the benefits caused by the tax deduction for the interests exceed the possible costs of financial stress ${ }^{1}$ caused by high indebtedness (Myers, 2001; Scott, 1976). According to Bradley et al. (1984, p. 857): "Although not a consensus, the general academic perspective of the mid-60s was that the optimal structure implied balancing the tax advantages of debt and the current value of the bankruptcy costs."

On this basis, in the late 70s, Miller proposed adjustments to the initial market efficiency theory mentioning that the capital structure effectively depends on the advantages of indebtedness versus its related costs (Miller, 1977); however, his model also argued that "the existence of an optimal capital structure is, in essence, an empirical problem on whether the various costs related to leveraging are economically significant enough to affect the costs of corporate loans." (Bradley et al., 1984, p. 857).

Miller's arguments concur with what other authors have proposed through empirical evidence, effectively showing that the mere trade-off between the costs and benefits of debt fails to answer all of its questions.

It does not justify why highly profitable enterprises in the same sector continue to finance themselves with their funds and do not use their debit capacity; why, in countries where taxes have been reduced or where the tax system reduces the debt's tax advantage, indebtedness continues to be high; nor why enterprises depart from the target capital structure for extended periods (Rivera, 2002, p. 53).

1 Namely bankruptcy costs. 
2.1.3. Pecking order theory. This theory emerges when considering another element of imperfect markets: asymmetricalinformation. When enterprises have information unknown to investors or vice versa, there is an information inequality, leading to financing decisions based on intrinsic hierarchies or preferences of the individuals. According to this theory, enterprises prefer internal financing over external financing, as the former is less risky; furthermore, should they have to resort to external financing (once the internal resources are depleted), enterprises prefer debt over capital (Myers and Majluf, 1984). In this line, Donaldson (2000, p. 67) argues that "the administration strongly favors the internal creation as a source of new funds, even with the exclusion of external funds, except for the inevitable increased need for funds."

In terms of debt, the theory notes that enterprises will always begin with the "safest" option, such as bonds; then, they will resort to the riskiest option; later, they will choose hybrids, such as convertible bonds or similar instruments; finally, they will select stocks (Myers, 1984). Again, just as in the trade-off theory, the costs of financial stress are relevant, as once the internal funds are depleted, enterprises may incur in large amounts of debt if and only if the debt-related risks do not exceed its benefits (Shyam and Myers, 1999).

Under this perspective, there cannot be a clear definition of the optimal capital structure, as the division between debt and capital becomes complex when considering that the capital can be both internal and external and that preferences will vary in both cases (Myers, 1984).

\subsection{Other representative theories}

2.2.1. Static equilibrium theory. This theory argues that a critical determinant of an enterprise's capital structure is its liquidity. Therefore, it states that to the extent that an enterprise has more liquidity, it will be more inclined to increase its debt, considering its high payment capacity (Rodríguez-Masero, and López-Manjón, 2016).

2.2.2. Free cash flow theory. The main focus of this theory is framed in one of the characteristics of imperfect markets: agency costs. Jensen (1986, p. 324) argues that:

The payments to shareholders reduce the resources controlled by managers, thus reducing the managers' powers and increasing the probability they incur in monitoring capital markets, which occurs when the company must obtain new capital. Internally financing projects prevents this monitoring and the possibility that the funds are not available or are only available at high explicit prices.

2.2.3. Signaling theory. Some theoretical positions agree that the management of an organization may have the intention of signaling objectives or behaviors to investors and other market players as it adopts financing decisions and defines a capital structure for the enterprise (Barclay, Smith, and Watts, 1995). The most common example of the application of this theory is related to indebtedness: "Adding more debt to an enterprise's capital structure can serve as a credible signal of high future cash flows" (Barclay et al., 1995, p. 11). However, other signaling mechanisms used in financing decisions are related to dividend policies, stock reacquisition, mergers, acquisitions, and more.

2.2.4. Corporate strategy. This focus claims that the corporate strategy of firms affects their capital structure (Arias, Casino, and López, 2003).

High-risk strategies, or those that hinder the lender from monitoring the use of the funds loaned, may restrict the access to the credit market or, at least, force the payment of high compensation premiums. On the contrary, strategies which offer guarantees to recover the funds' amount, such as using high collateral or risk diversification strategies (by operating with several business lines or market segmentation), facilitate the access to new sources of external financing (Arias et al., 2003, p. 31).

This way, there is a relationship between the firm's performance or its behavior in the market and its capital structure, mainly shown in the access to and the securing of funds.

All the theories proposed so far contain relevant aspects for the financial study of 
enterprises, and, depending on their specific context, their application may or may not be beneficial. However, although several theories have emerged on the capital structure of enterprises, a common denominator in the literature is the focus on that there is no general theory on making adequate financial decisions and on the optimal capital structure (Myers, 2001; Psillaki \& Daskalakis, 2009).

\subsection{Behavioral finance and capital structure}

Behavioral finance has been gaining traction recently. This field also attempts to explain the financial decisions of agents, framing said decisions in psychology (Shefrin, 2002). Therefore, it claims that individuals have systemic biases to make decisions, caused by two psychological factors: beliefs and preferences (Barberis and Thaler, 2003).

This branch of finance claims that the two main pillars of traditional corporate finance - rational behavior and the markets' efficiency - are not met because individuals are influenced by psychological forces (mainly emotional influences), which interfere with the rationality of their behavior (Shefrin, 2001). "In general terms [behavioral finance] claims that some financial phenomena can be better understood by using models in which some agents are not entirely rational" (Barberis and Thaler, 2003, p. 1054). Additionally, it also claims that arbitration, as a method for mediation between rational and irrational individuals proposed by the efficient market theory, is risky and limited, and, therefore, accommodates price deviations and market inefficiencies (Shleifer, 2000).

Reasonably, this branch of finance is justified because most of the theories on capital structure have not been entirely demonstrated with empirical evidence, as factors related to the irrational behavior of individuals have interfered with the process.

\subsection{Application of the capital structure theories and financing decisions to SMES}

The case of the capital structure for SMEs is even more debated in academic financial literature. These enterprises are of great importance for global studies since it is well known that they form a significant part of the corporate fabric both in developed and in developing countries (Sogorb-Mira, 2005). Therefore, several authors have attempted to demonstrate the effectiveness of the main theoretical approaches in the specific case of SMEs.

Regarding the initial approach by Modigliani \& Miller, the hypothesis of efficient markets is easily dismissed for SMEs because these enterprises do not operate under perfect markets and are not listed; therefore, prices cannot reflect all the available information.

In the context of imperfect markets, some authors such as Pettit and Singer (1985) and Sogorb-Mira (2005) have demonstrated that, in most cases, the trade-off theory does not apply to SMEs as the taxes for these enterprises are not as relevant to the extent that their profitability is low or negative; therefore, they can hardly obtain any benefit from the interests paid on debts. Similarly, there are other, less risky "tax shields" than debt, such as depreciation, deductions for investments, and $R \& D$ expenses (SogorbMira, 2005).

In turn, Sogorb-Mira (2005) claims that the signaling theory cannot be applied to SMEs because these enterprises "are not listed and, therefore, their management has no intentions whatsoever of signaling something to the markets and investors as they adopt financing decisions" (p. 7).

The free cash flow theory has a more complex application. To the extent that SMEs are financed with the funds of their owners, who also act as the managers, the agency costs are very low or null; however, when these enterprises resort to debt, the agency costs increase dramatically as lenders, seeing little credit history, require very high collaterals and impose high interest rates (Psillaki and Daskalakis, 2009).

Regarding the static equilibrium theory, whether SMEs increase their indebtedness as their liquidity (repayment capacity) increases or as they need resources (absence of internal funds) is disputed. Therefore, whether or not this theory applies to them depends on the specific context of the enterprise. 
Regarding the corporate strategy theory for SMEs, Arias et al. (2003, p. 31) argue that:

Credit markets could perceive diversification strategies as a negative signal of their management considering the need of enterprises to firmly consolidate a determined business before undertaking such tasks with hopes of success.

In general, SMEs differ substantially from large enterprises in strategic terms. Similarly, several competitive strategies may result in different economic results. Therefore, applying this theory also requires a careful analysis of the context of each SME, its corporate strategy, and its commitment to financing sources.

However, the pecking order theory can be applied closer in the context of SMEs because the information asymmetry is much more significant than in big enterprises (Arias et al., 2003). SMEs usually prefer using internal funds because the owners are often the managers and, provided they have the resources, will choose to finance the firms activities themselves; thus, if they require external funds, they will usually resort to debt as SMEs have limited access to the stock market (Sogorb-Mira, 2005). However, it is argued that the main reason to adopt these financing decisions has little relation with achieving an optimal capital structure and is much closer to minimize the participation of external agents in the ownership of the enterprise (Arias et al., 2003).

These trends may even be combined with the assumptions of behavioral finance to the extent that the owners and managers of SMEs do not like to lose control over their companies and, therefore, are reluctant to accept new investments, preferring internal funds or even indebtedness (Hamilton and Fox, 1998). According to Norton (1991, p. 174):

In small business and ventures, the beliefs and wishes of managers play a specially significant role in determining the capital structure (...) the models must include the role of preferences, beliefs, and expectations of the management if we want to understand their capital structure policy better.
On the other hand, some research has attempted to demonstrate which factors other than those mentioned in the main theories may affect the capital structure of SMEs. Jiménez and Palacin (2007) demonstrated that, at least in Spain, the size of the enterprises and their sector of operations significantly affects their capital structure.

On the one hand, and regarding the sector, some arguments justify their relationship with the enterprise's indebtedness (...), the importance of the industry lies in the fact that enterprises from the same sector should have a similar financial structure because, as the economic risk varies, the asset composition and the need for resources varies between industries. On the other hand, (...) we can briefly see the relationship between the size and the insolvency costs, the issuing costs, the agency costs, and the asymmetrical information problems (Jiménez and Palacín, 2007, p. 11).

In turn, The World Bank (2008) and VeraColina et al. (2014) argued that the availability of sources is a critical factor in making financing decisions for SMEs, as it affects the options available to said companies at determined times and, therefore, their capital structure.

\section{Methodology}

The methodological design of this research is aimed at characterizing how the specific analysis population make financing decisions. For the results to be representative of a given population, we decided to choose a sufficiently delimited population sample for the study. Therefore, considering the current boom of orange economy ${ }^{2}$ In Colombia and its inclusion as one of the pillars of the current national and territorial development plans, we chose the cultural and creative SMEs of Bogotá as population.

According to figures by Bogotá Chamber of Commerce, Bogotá's Mayor Office and UNESCO (2018), by late 2018, there were 28,046 SMEs in the cultural and creative sector registered in Bogotá, distributed

2 Term coined in Colombia to refer to "creative economy," i.e., the creation of wealth through ideas, intellectual property, talent, heritage, and culture. 


\begin{tabular}{|c|c|c|}
\hline Question & Possible answers & Theory compared \\
\hline $\begin{array}{l}\text { When financing your company, you (and other } \\
\text { owners or managers) prefer: }\end{array}$ & $\begin{array}{c}\text { Internal sources: own capital } \\
\text { External sources, Bank loans or bonds } \\
\text { External sources: share or other capital } \\
\text { instruments }\end{array}$ & Pecking order \\
\hline $\begin{array}{c}\text { When asking for a bank loan for your company, } \\
\text { do you consider that the debt interests are } \\
\text { tax-deductible? }\end{array}$ & $\begin{array}{c}\text { Yes } \\
\text { No } \\
\text { No knowledge } \\
\text { Does not use bank loans to acquire funds }\end{array}$ & Trade-off \\
\hline $\begin{array}{l}\text { Do you believe that the debt-related financial costs } \\
\text { (interests, financial stress, possible lack of future } \\
\text { liquidity, liens, etc.) are important? }\end{array}$ & $\begin{array}{c}\text { Yes } \\
\text { No } \\
\text { No knowledge }\end{array}$ & Trade-off \\
\hline $\begin{array}{c}\text { If you had greater liquidity (more cash on hand), } \\
\text { would you increase the loans requested to } \\
\text { financial entities? }\end{array}$ & $\begin{array}{l}\text { Yes } \\
\text { No }\end{array}$ & Static equilibrium \\
\hline $\begin{array}{l}\text { What additional factors do you believe affect your } \\
\text { financing decisions? }\end{array}$ & $\begin{array}{l}\text { Need } \\
\text { Availability (whatever is easier or quicker to } \\
\text { access) } \\
\text { Preferences, beliefs, intentions or emotional } \\
\text { influences } \\
\text { Repayment costs and conditions (interest } \\
\text { rates, payment terms, requirements, etc.) } \\
\text { Prevent increasing the number of partners } \\
\text { (prevent giving control to third parties) } \\
\text { Analyze the sources of information used by } \\
\text { similar companies (same sector or size) }\end{array}$ & $\begin{array}{c}\text { Behavioral finance } \\
\text { Trade-off } \\
\text { Pecking order } \\
\text { Free cash flow } \\
\text { Corporate strategy } \\
\text { Additional factors }\end{array}$ \\
\hline
\end{tabular}

in five main activities: audiovisual, music, performing arts, plastic arts, and publishing.

For this paper, we chose a behavior-based empirical research method in the financial area. This method intends to include individuals in prediction and characterization models, mainly in financial decision-making, assuming that said individuals depart from the regulatory models considering the use of heuristic thinking (Ryan, Scapens, and Theobald, 2004). Consequently, we designed surveys and interviews to characterize the attitudes and explore the opinions of the target population. In the surveys, we identified behaviors related to the assumptions proposed by each capital structure theory studied in the literature review above and wrote them as closed questions to place the interviewee in a category. Table 1 shows the questions asked during the survey, the possible answers, and the theories compared. For the interviews, we asked about the experiences of entrepreneurs in the cultural and creative sector regarding the financing of their business.

Considering the size of the population and the logistical difficulties of applying the surveys and interviews to everyone, we made a simple random probabilistic sampling. To select the sample size, we used a $95 \%$ confidence level, a $6 \%$ margin of error and a $0.5^{3}$ expected proportion, resulting in a sample of 264 companies. The surveys and interviews were contacted throughout six months. Surveys were sent to the sample selected via email, and the interviews were conducted through visits and phone calls, which were recorded and subsequently documented.

\section{Results and Discussion}

To distinguish the main traits of the

3 Standard value to obtain the maximum sample size considering the difficulty of estimating an appropriate proportion. 
companies surveyed, we included questions to characterize the target population. Table 2 shows the companies that answered the survey: $83.95 \%$ are small enterprises, whereas $16.05 \%$ are medium enterprises ${ }^{4}$. Additionally, the table also shows the economic activities of these companies, where the main activity is the audiovisual industry, and the lowest activity is plastic arts.

\begin{tabular}{|c|c|c|}
\hline \multicolumn{3}{|c|}{ Corporate size } \\
\hline Variable & Total & Percentage \\
\hline Small & 221 & 83.71 \\
\hline Medium & 43 & 16.29 \\
\hline \multicolumn{3}{|c|}{ Economic activity performed } \\
\hline Variable & Total & Percentage \\
\hline Audiovisual & 141 & 53.31 \\
\hline Music & 104 & 39.50 \\
\hline Performance arts & 85 & 32.10 \\
\hline Publishing & 39 & 14.80 \\
\hline Plastic arts & 26 & 9.90 \\
\hline
\end{tabular}

Note: Out of the 264 companies surveyed, some are engaged in two or more economic activities.

Source: Author own elaboration.

\subsection{Comparison of capital structure theories}

Graph 1 shows that medium enterprises have no specific preference regarding the source of financing resources. Therefore, in this particular case, there is no evidence relating the companies surveyed with the central assumption of the pecking order theory. On the other hand, regarding small enterprises, the graph shows that most of them prefer using internal resources; however, when comparing the external sources, they prefer using shares or other capital instruments over bank loans, diverging from said theory.

Graph 2 shows - once again - that there is no significant difference for medium enterprises on whether or not they consider the tax benefits of indebtedness when taking bank loans. In the case of small enterprises, most of them state that they do not use bank loans to acquire funds; if they use them, most of them did not know that the interests paid are tax-deductible. As in the previous case, the results differ from the theory -in this case, trade-off-, although more companies consider said fiscal benefits as part of their financial decisions, most of them did not know about them or chooses not to use them.

Graph 1. Preference for financing resources source

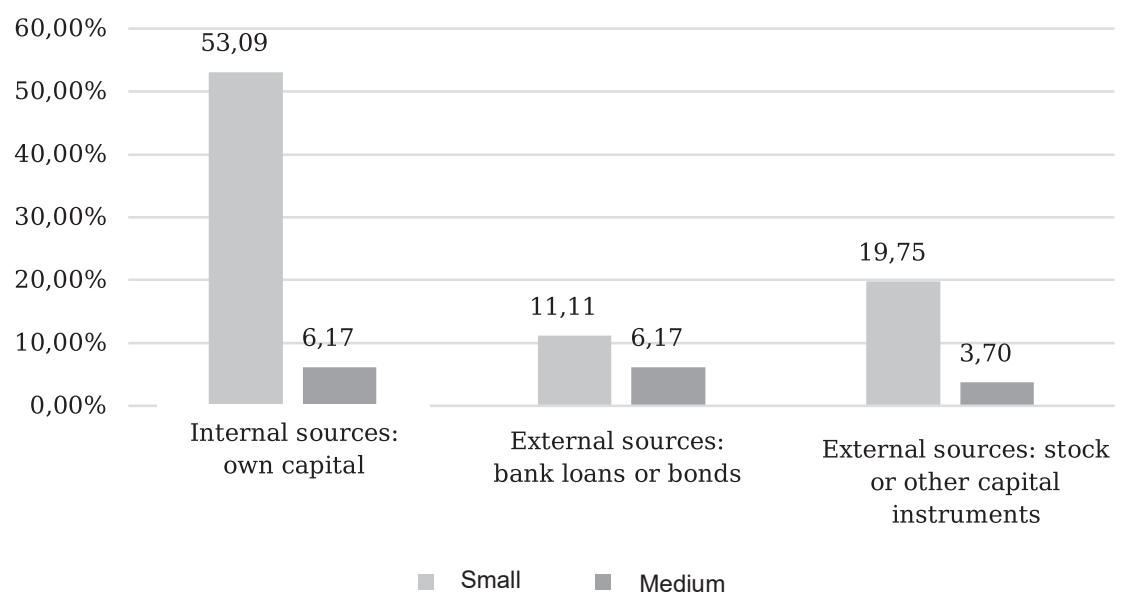

Source: Author own elaboration.

Classified as per the guidelines of Law 590/2000 and Law 905/2004. 


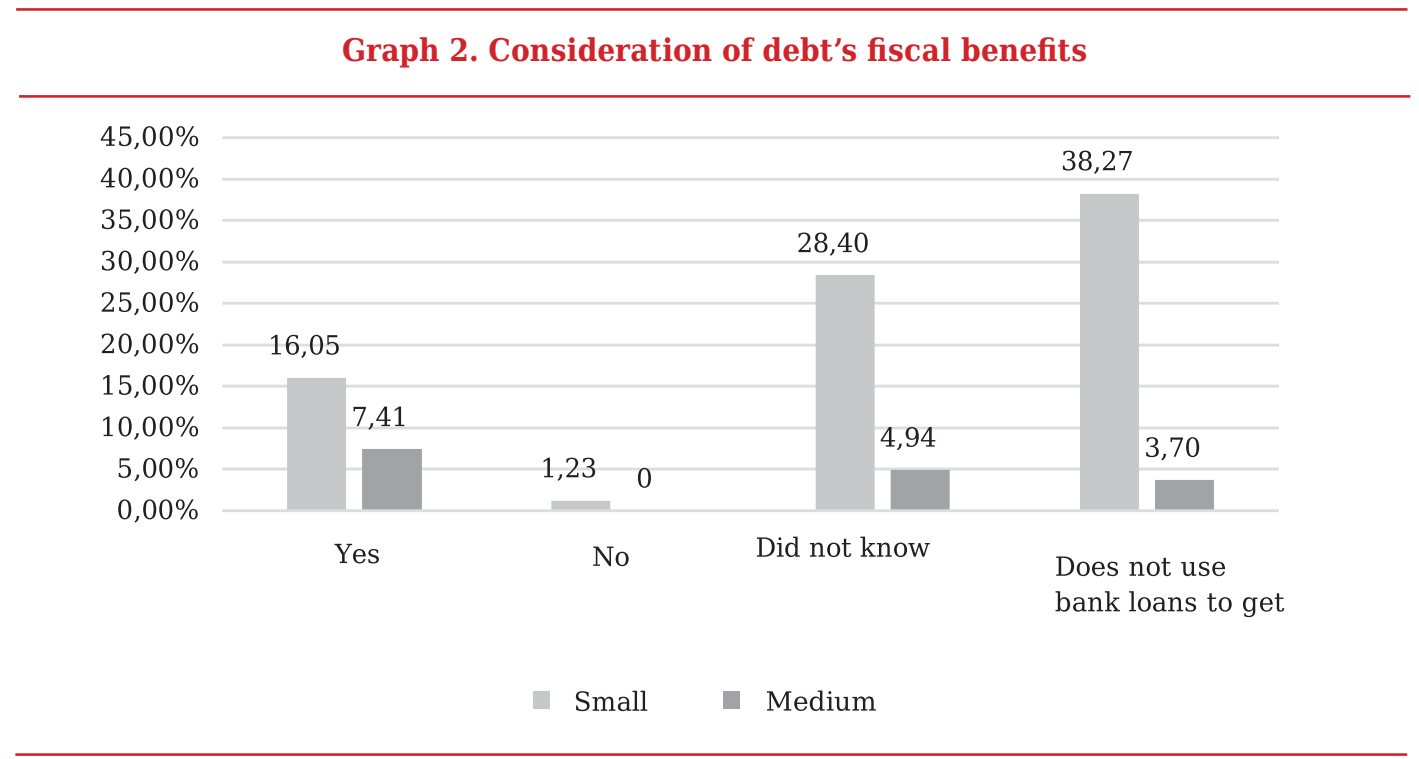

Source: Author own elaboration.

Graph 3. Consideration of the debt-related financial costs

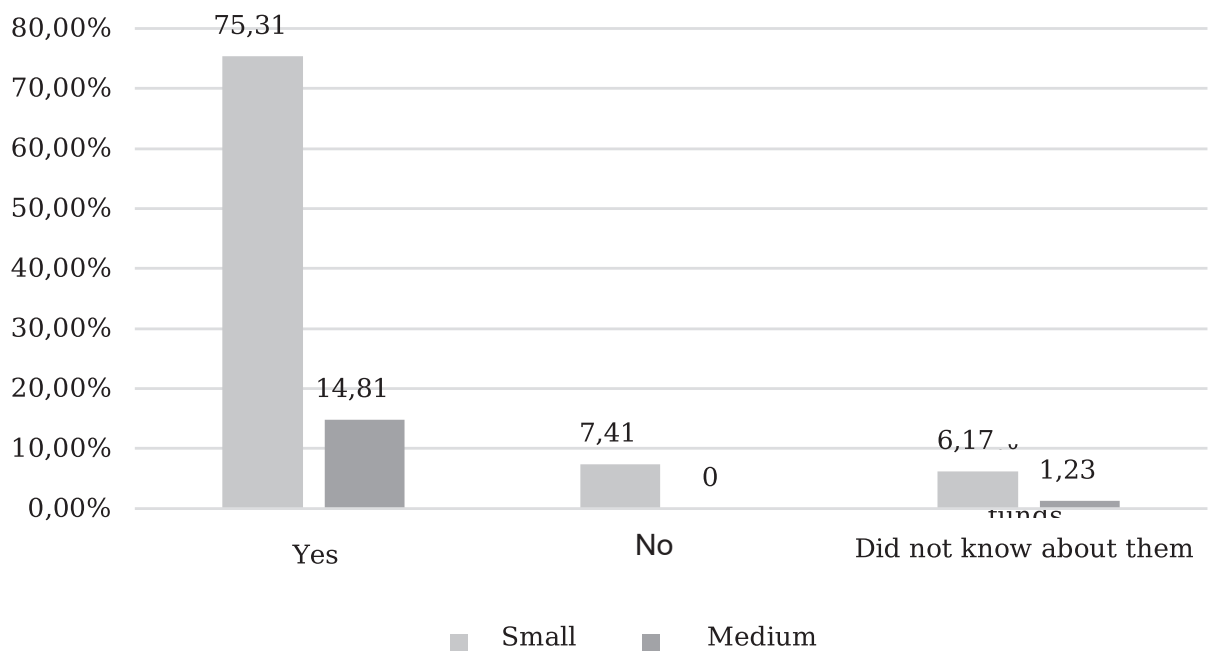

Source: Author own elaboration.

Graph 3 clearly shows that both small and medium enterprises believe that debtrelated financial costs are important. This behavior is positively related to the tradeoff theory's approach to the extent that enterprises consider it when increasing their indebtedness; however, this relationship is not entirely clear. By comparing them with the results of Graph 2, we could say that companies increase their debt as long as its disadvantages do not exceed its benefits, as most individuals of the sample considered do not use bank loans or do not know its tax benefits.

Graph 4 shows that the low use of bank loans by the companies surveyed, as seen in the results tabulated in the graphs above, cannot be related to what the static equilibrium theory proposes. Contrary to this theory, most of the entrepreneurs surveyed are not likely to increase their indebtedness in the near future if they had more liquidity on hand. 


\section{Graph 4. Willingness to increase indebtedness if they had greater liquidity}

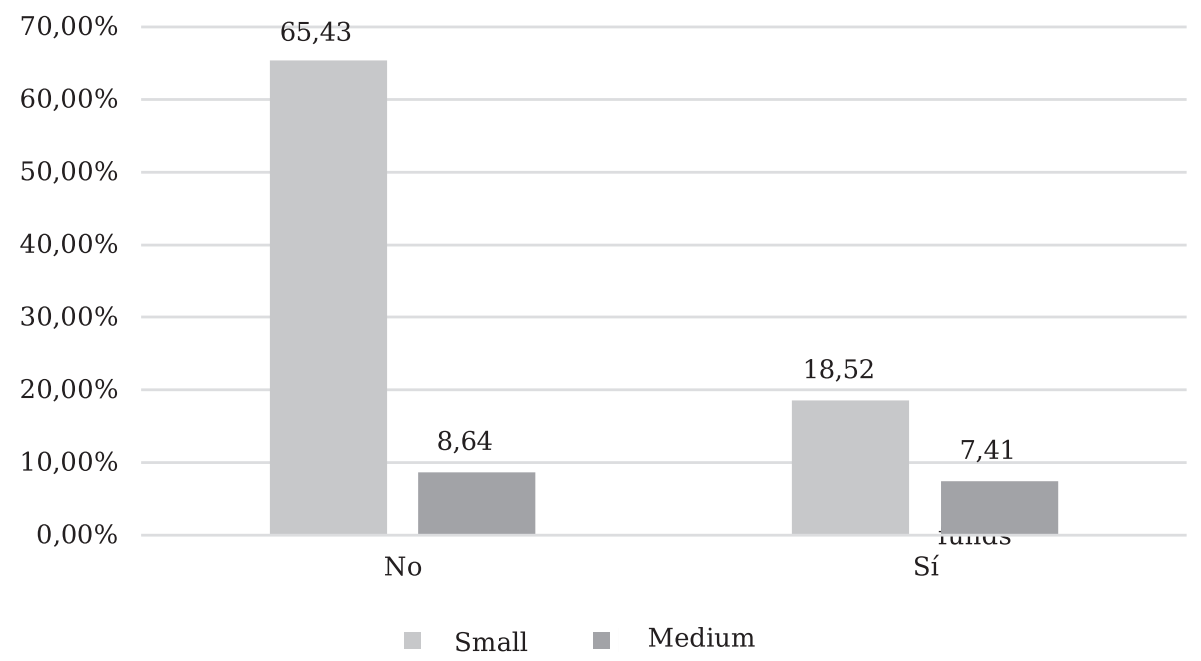

Source: Author own elaboration.

\begin{tabular}{|c|c|c|c|c|}
\hline Factor & Theory compared & Options & $\begin{array}{c}\text { Small } \\
\text { Enterprise (\%) }\end{array}$ & $\begin{array}{c}\text { Medium } \\
\text { Enterprise (\%) }\end{array}$ \\
\hline \multirow{3}{*}{ Source of resources } & \multirow{3}{*}{ Pecking order } & Internal sources: own capital & 53.09 & 6.17 \\
\hline & & $\begin{array}{c}\text { External sources, Bank loans or } \\
\text { bonds }\end{array}$ & 11.11 & 6.17 \\
\hline & & External sources: stock & 19.75 & 3.70 \\
\hline \multirow{4}{*}{$\begin{array}{l}\text { Consideration of the debt's } \\
\text { fiscal benefits }\end{array}$} & \multirow{4}{*}{ Trade-off } & Yes & 16.05 & 7.41 \\
\hline & & No & 1.23 & 0 \\
\hline & & No knowledge & 28.40 & 4.94 \\
\hline & & Does not use bank loans & 38.27 & 3.70 \\
\hline \multirow{3}{*}{$\begin{array}{l}\text { Consideration of debt-related } \\
\text { financial costs }\end{array}$} & \multirow{3}{*}{ Trade-off } & Yes & 75.31 & 14.81 \\
\hline & & No & 7.41 & 0 \\
\hline & & No knowledge & 6.17 & 1.23 \\
\hline \multirow{2}{*}{$\begin{array}{l}\text { Willingness to increase } \\
\text { indebtedness as liquidity } \\
\text { increases }\end{array}$} & \multirow{2}{*}{ Static equilibrium } & No & 65.43 & 8.64 \\
\hline & & Yes & 18.52 & 7.41 \\
\hline
\end{tabular}

Table 3 summarizes the results shown in the above graphs and the percentage of small and medium enterprises of the creative and cultural sector surveyed, which behave according to the assumptions of each of the theories compared during this research stage.

\subsection{Factors considered by entrepreneurs} to make financing decisions

Table 4 shows the additional factors considered by entrepreneurs as those that affect their financing decisions according to their relative importance. The table shows 
that, according to entrepreneurs, the main factor is the need (which is not explicitly related to any of the main capital structure theories). Additionally, the repayment costs and conditions, which are mostly contextual factors related to agency costs (according to the free cash flow theory), are also a prevailing factor for the companies surveyed when making financial decisions. On the other hand, the target population considers factors related to corporate strategy, behavioral finance, and pecking order theories as less critical.

Table 4. Additional Factors Affecting Financing Decisions

\begin{tabular}{|l|c|c|}
\hline \multicolumn{1}{|c|}{ Factor* } & Total & \% \\
\hline Need & 173 & 65.40 \\
\hline $\begin{array}{l}\text { Repayment costs and conditions } \\
\text { (interests rates, payment terms, } \\
\text { requirements, etc.) }\end{array}$ & 134 & 50.60 \\
\hline $\begin{array}{l}\text { Analyze the sources of information } \\
\text { used by similar companies (same } \\
\text { sector or size) }\end{array}$ & 91 & 34.60 \\
\hline $\begin{array}{l}\text { Availability (whatever is easier or } \\
\text { quicker to access) }\end{array}$ & 78 & 29.60 \\
\hline $\begin{array}{l}\text { Prevent increasing the number of } \\
\text { partners (prevent giving control to } \\
\text { third parties) }\end{array}$ & 46 & 17.30 \\
\hline $\begin{array}{l}\text { Preferences, beliefs, intentions or } \\
\text { emotional influences }\end{array}$ & 23 & 8.60 \\
\hline
\end{tabular}

Note: In this question, each interviewee could select more than one factor.

Source: Author own elaboration.

Based on the interviews with some of the companies selected by the statistical sample, we may infer that several contextual factors affect the financial decision-making process. For most of the SMEs interviewed, financing through bank loans is an issue that is not within their possibilities due to the inherent difficulties and risks. SMEs usually do not resort to bank loans mainly for two reasons, according to the results of the surveys and interviews with entrepreneurs: 1) They prefer to avoid this type of debt due to the inherent costs and conditions; and 2) In most cases, financial entities are reluctant to grant loans because "they are more stringent in evaluating requests for resources by SMEs, grading their proposals as risky and less attractive" (Vera-Colina et al., 2014 p. 158).
Consequently, many interviewees mentioned that they faced several challenges to finance their enterprises. On the one hand, although they have attempted to obtain bank loans on several occasions, they have not been able to due to their credit history, their economic activity, and the size of their enterprises. On the other hand, although there has been a series of state-run calls for proposals to finance SMEs in the creative and cultural sector during the last years, the interviewees believe that the resources awarded by these calls for proposals are very hard to obtain, are not enough, or are not commensurate to the needs of these entities.

\section{Conclusions}

The academic and research interest in knowing the factors that condition the financing decisions of companies, and how these decisions affect their performance has increased in the last few years. However, the literature on this issue has mostly focused on large listed companies and who have a broad range of financing options. More recently, the literature has focused on explaining the SMEs' financing decisions at a global level.

In this study, we examined the specific case of creative and cultural SMEs in Bogotá. For these companies, we observed certain coincidences and divergences with the main academic theories on capital structure and with the research conducted around the world to test these theories. At first glance, the theory that has been most tested with SMEs in the literature is the pecking order theory, which matched the results found only regarding the internal financing sources. The behavior differs for external sources. Furthermore, we found that, at least in the context of the SMEs surveyed, their financing decisions do not agree to the statements of the trade-off, signaling, or static equilibrium theories.

Factors related to needs, preferences, and competitiveness cause certain similarities between the results and the corporate strategy, free cash flow, and behavioral finance theories. However, not all of the assumptions of said theories apply due to the increasingly variable context of the SMEs in this sector. Therefore, there are several 
factors inherent to the Colombian economy related to insufficient access to both public and private financing sources, which affect the decision-making process.

Finally, there is still a vast grey area to explore in research and academic terms. More in-depth national and international research should be conducted for SMEs and financing decisions prediction models developed for these enterprises. Based on the results obtained, it is also appropriate to design public policy strategies to increase the number of financing sources available to these entities to improve the national and global corporate growth.

\section{Conflict of interest}

The author declares no conflict of interest.

\section{Source of Financing}

This research is sponsored by Research Office of Fundacion Universitaria Los Libertadores (SMEs of Cultural Industries, an alternative to achieve Sustainable Development in Bogotá).

\section{References}

Arias, A., Casino, A., y López, J. (2003). Estrategia y estructura de capital en la PYME: una aproximación empírica. Estudios de Economía aplicada, 21(1), 27-52. Retrieved from https:// www.redalyc.org/pdf/301/30121108.pdf

Barberis, N., \& Thaler, R. (2003). A survey of behavioral finance. Handbook of the Economics of Finance, 1, 1053-1128. http://dx.doi. org/10.2139/ssrn.327880

Barclay, M., Smith, C., \& Watts, R. (1995). The determinants of corporate leverage and dividend policies. Journal of applied corporate finance, 7(4), 4-19. https://doi. org/10.1111/j.1745-6622.1995.tb00259.x

Bradley, M., Jarrell, G., \& Kim, E. (1984). On the Existence of an Optimal Capital Structure: Theory and Evidence. The Journal of Finance, 39(3), 857-878. DOI: 10.2307/2327950

Cámara de Comercio de Bogotá, Alcaldía Mayor de Bogotá y UNESCO. (2018). Caracterización de Industrias Culturales y Creativas. Bogotá D.C,
Colombia: Centro de Información Empresarial (CIEB). Retrieved from https://bibliotecadigital. ccb.org.co/handle/11520/20339

Donaldson, G. (2000). Corporate debt capacity: A study of corporate debt policy and the determination of corporate debt capacity. Beard Books.

Fama, E. (1970). Efficient Capital Markets: A Review of Theory and Empirical Work. The Journal of Finance, 25(2), 383-417. http://dx.doi. org $/ 10.2307 / 2325486$

Hamilton, R., \& Fox, M. (1998). The financing preferences of small firm owners. International Journal of Entrepreneurial Behavior \& Research, 4(3), 239-248. http://dx.doi. org/10.1108/13552559810235529

Jensen, M. (1986). Agency costs of free cash flow, corporate finance, and takeovers. The American economic review, 76(2), 323-329. http://dx.doi. org/10.2139/ssrn.99580

Jiménez, F., \& Palacín, M. (2007). Determinantes de la estructura financiera de la empresa. Revista europea de dirección y economía de la empresa, 16(4), 9-23. Retrieved from https:/l www.researchgate.net/publication/28199977 Determinantes de la estructura financiera de_la_empresa

Miller, M. (1977). Debt and Taxes. The Journal of Finance, 32(2), 261-275. DOI: http://dx.doi. org/10.2307/2326758

Modigliani, F., \& Miller, M. (1958). The Cost of Capital, Corporate Finance, and the Theory of Investment. American Economic Review, 48, 261-297. Retrieved from http://links.jstor.org/ sici?sici=0002-8282\%28195806\%2948\%3A3\%3 C261\%3ATCOCCF\%3E2.0.CO\%3B2-3

Modigliani, F., \& Miller, M. (1963). Corporate Income Taxes and the Cost of Capital: A Correction. The American Economic Review, 53, 147-175. Retrieved from http://www.jstor.org/ stable/1809167

Myers, S. (1984). The capital structure puzzle. The journal of finance, 39(3), 574-592. http:// dx.doi.org/10.2307/2327916

Myers, S. (2001). Capital Structure. Journal of Economic Perspectives, 15(2), 81-102. http:// dx.doi.org/10.1257/jep.15.2.81

Myers, S., \& Majluf, N. (1984). Corporate financing and investment decisions when firms have information that investors do not have. Journal of Financial Economics, 13, 187-221. http:// dx.doi.org/10.1016/0304-405X(84)90023-0 
Norton, E. (1991). Capital structure and small growth firms. Journal of Small Business Finance, 1(2), 161-177. Retrieved from https:// digitalcommons.pepperdine.edu/jef/vol1/iss $2 / 6$

Pettit, R., \& Singer, R. (1985). Small business finance: a research agenda. Financial Management, 14(3), 47-60. http://dx.doi. org/10.2307/3665059

Psillaki, M., \& Daskalakis, N. (2009). Are the determinants of capital structure country or firm specific? Small Business Economics, 33(3), 319-333. http://dx.doi.org/10.1007/ s11187-008-9103-4

Rivera, G. (2002). Teoría sobre la estructura de capital. Estudios gerenciales, 18(84), 31-59. Retrieved from http://ref.scielo.org/qdf5bg

Rodríguez-Masero, N., \& López-Manjón, J. (2016). El flujo de caja como determinante de la estructura financiera de las empresas españolas. Un análisis en tiempos de crisis. Revista de Métodos Cuantitativos para la Economía y la Empresa, 21, 141-159. Retrieved from https://www.upo.es/revistas/index.php/ RevMetCuant/article/view/2257

Ryan, B., Scapens, R., \& Theobald, M. (2004). Metodología de la Investigación en Contabilidad y Finanzas. Barcelona, España: Deusto.

Scott, J. (1976). A Theory of Optimal Capital Structure. The Bell Journal of Economics, 7(1), 33-54. DOI: http://dx.doi.org/10.2307/3003189

Shefrin, H. (2001). Behavioral Corporate Finance. Journal of Applied Corporate Finance, 14(3), 113-124. http://dx.doi.org/10.2139/ssrn.288257
Shefrin, H. (2002). Beyond greed and fear: Understanding behavioral finance and the psychology of investing. Oxford, United Kingdom: Oxford University Press on Demand.

Shleifer, A. (2000). Inefficient markets: An introduction to behavioural finance. Oxford, United Kingdom: OUP Oxford.

Shyam, S., \& Myers, S. (1999). Testing static tradeoff against pecking order models of capital structure. Journal of financial economics, 51(2), 219-244. Retrieved from https://www.nber.org/ papers/w4722.pdf

Sogorb-Mira, F. (2005). How SME uniqueness affects capital structure: Evidence from a 1994-1998 Spanish data panel. Small business economics, 25(5), 447-457. https://doi. org/10.1007/s11187-004-6486-8

The World Bank. (2008). Finance for all? Policies and pitfalls in expanding access. World Bank Policy Research Report. Washington: The International Bank for Reconstruction and Development/The World Bank. Retrieved from www.worldbank.org

Vargas, A. (2012). Estimación del Costo del Patrimonio y Costo del Capital por medio de tasas de rendimiento ajustadas al riesgo. Revista Investigación \& Desarrollo, 1(11), 24-40. DOI: 10.23881/idupbo.011.1-2e

Vera-Colina, M., Melgarejo-Molina, Z., \& MoraRiapira, E. (2014). Acceso a la financiación en Pymes colombianas: una mirada desde sus indicadores financieros. INNOVAR. Revista de Ciencias Administrativas y Sociales, 149-160. https://doi.org/10.15446/innovar.v24n53.43922

¿How to quote this article?

Navarro Pérez, P. A. (2020). Financing Decisions for Creative and Cultural SMEs in Bogotá, Colombia. Cuadernos de Administración, 36(66), 92-104. https://doi.org/10.25100/cdea.v36i66.8426

Cuadernos de Administración journal by Universidad del Valle is under licence Creative Commons Reconocimiento-NoComercial-SinObrasDerivadas 4.0. Based in http://cuadernosdeadministracion.univalle.edu.co/ 